\title{
Hospital and urban effluent waters as a source of accumulation of toxic metals in the sediment receiving system of the Cauvery River, Tiruchirappalli, Tamil Nadu, India
}

\author{
Naresh Devarajan ${ }^{1}$ • Amandine Laffite ${ }^{1}$ - Patience Ngelikoto ${ }^{2}$. \\ Vicky Elongo ${ }^{3} \cdot$ Kandasamy Prabakar $^{4}$. Josué I. Mubedi ${ }^{2}$. \\ Pius T. M. Piana ${ }^{5}$. Walter Wildi ${ }^{1}$ John Poté ${ }^{1,2,5}$
}

Received: 13 January 2015 / Accepted: 27 March 2015 /Published online: 28 April 2015

(C) Springer-Verlag Berlin Heidelberg 2015

\begin{abstract}
Hospital and urban effluents contain a variety of toxic and/or persistent substances in a wide range of concentrations, and most of these compounds belong to the group of emerging contaminants. The release of these substances into the aquatic ecosystem can lead to the pollution of water resources and may place aquatic organisms and human health at risk. Sediments receiving untreated and urban effluent waters from the city of Tiruchirappalli in the state of Tamil Nadu, India, are analyzed for potential environmental and human health risks. The sediment samples were collected from five hospital outlet pipes (HOP) and from the Cauvery River Basin (CRB) both of which receive untreated municipal effluent waters (Tiruchirappalli, Tamil Nadu, India). The samples were characterized for grain size, organic matter, toxic metals, and ecotoxicity. The results highlight the high concentration of
\end{abstract}

Responsible editor: Philippe Garrigues

John Poté

john.pote@unige.ch

1 University of Geneva, Faculty of Sciences, Earth and Environmental Science, F. A. Forel Institute and Institute of Environmental Sciences, CP 416, 1290 Versoix, Switzerland

2 Université Pédagogique Nationale (UPN), Croisement Route de Matadi et Avenue de la Libération, Quartier Binza/UPN, B.P. 8815, Kinshasa, Democratic Republic of the Congo

3 Faculté des Lettres et Sciences Humaines, Département des Sciences de l'Information et de la Communication, Université de Kinshasa, B.P. 243, Kinshasa XI, Democratic Republic of the Congo

4 Department of Zoology, Jamal Mohamed College, Tiruchirappalli 620020, Tamil Nadu, India

5 Faculty of Science, Department of Chemistry, University of Kinshasa (UNIKIN), B.P. 190, Kinshasa XI, Democratic Republic of the Congo toxic metals in HOP, reaching values $\left(\mathrm{mg} \mathrm{kg}^{-1}\right)$ of 1851 $(\mathrm{Cr}), 210(\mathrm{Cu}), 986(\mathrm{Zn}), 82(\mathrm{~Pb})$, and $17(\mathrm{Hg})$. In contrast, the metal concentrations in sediments from $\mathrm{CRB}$ were lower than the values found in the HOP (except for $\mathrm{Cu}, \mathrm{Pb}$ ), with maximum values $\left(\mathrm{mg} \mathrm{kg}^{-1}\right)$ of $75(\mathrm{Cr}), 906(\mathrm{Cu}), 649(\mathrm{Zn})$, $111(\mathrm{~Pb})$, and $0.99(\mathrm{Hg})$. The metal concentrations in all sampling sites largely exceed the Sediment Quality Guidelines (SQGs) and the Probable Effect Concentration (PEC) for the Protection of Aquatic Life recommendation. The ecotoxicity test with ostracods exposed to the sediment samples presents a mortality rate ranging from 22 to $100 \%$ (in sediments from HOP) and $18-87 \%$ (in sediments from CRB). The results of this study show the variation of toxic metal levels as well as toxicity in sediment composition related to both the type of hospital and the sampling period. The method of elimination of hospital and urban effluents leads to the pollution of water resources and may place aquatic organisms and human health at risk.

Keywords Hospital effluent - Sediment receiving system . Toxic metals $\cdot$ Ecotoxicity $\cdot$ Human risk $\cdot$ India

\section{Introduction}

Hospitals perform a wide variety of activities (health care, hygiene, diagnostics, prophylaxis, etc.) for which they are a consumer of a variety of potentially toxic substances including drugs and their metabolites such as antibiotics, organic matter, radionuclides, solvents, metals, disinfectants, sterilization products, specific detergents for various instruments, radioactive markers, and iodinated contrast media (Verlicchi et al. 2010; Mubedi et al. 2013). Active substances in medicines are only metabolized to a certain extent on administration to patients. Following this, the mostly active un-metabolized 
substances are released through excretions into the effluents (Ternes and Joss 2006) and then released into the aquatic environment (Halling-Sorensen et al. 1998). Hospital effluents and urban runoff in most developing countries represent a significant source of many toxic elements in the aquatic environment because the effluents are discharged into drainage systems, rivers, and lakes without prior treatment, and then accumulate in sediments (Mubedi et al. 2013; Mwanamoki et al. 2014a, b). The main human and environmental risk is remobilization of the contaminants and their return to the hydrosphere either by sediment re-suspension or by infiltration into groundwater (Wildi et al. 2004). The modification of environmental conditions such as $\mathrm{pH}$, redox potential, bacterial activities, or ligand concentration leads to the release of contaminants from the sediment into the water column and increase their bioavailability (Cantwell et al. 2002; Gillan et al. 2005; Haller et al. 2011). As a result, polluted sediments also represent a significant source of contamination in fresh water organisms (Kang et al. 2000).

Tiruchirappalli city is the fourth largest city in the Tamil Nadu region of India with a population of 752,066 inhabitants (TMC 2001). The city is located in the central part of Tamil $\mathrm{Nadu}$, and the civic administration is divided into four areas and a total of 65 wards. The climate is tropical and the temperature usually $22-43{ }^{\circ} \mathrm{C}$. Cauvery Basin is estimated to be $81,555 \mathrm{~km}^{2}$ with many tributaries generally flowing to the south and east of the states of Karnataka and Tamil Nadu. The water source of the river primarily acts as a major source of drinking water for the inhabitants of the Tiruchirappalli region and as irrigation for the Cauvery delta (Kalavathy et al. 2011). Agriculture, urbanization, industrialization, and vegetation along the river bank are part of the economy in the Indian sub-continent. On the other hand, the river also acts as a receiving system for most of the anthropogenic pollution in the locality. Continuous monitoring of the water sources to validate sustainable progress and to monitor environmental pollution is important, including in the case of the Cauvery River.

Little information is available on the assessment of contaminants in receiving systems in developing countries (under tropical conditions). A previous study (Mubedi et al. 2013) presents various characteristic aspects of sediment receiving hospital effluent waters. However, there is no quantitative information regarding the characterization of sediments receiving municipal effluent waters as well as about ecotoxicological aspects in the Cauvery River (Tamil Nadu Region). The aim of the research presented in this paper is to assess the effects of untreated hospital and urban effluent waters on the accumulation of toxic metals in the sediment receiving systems in the Cauvery River Basin, Tiruchirappalli, Tamil Nadu, India. This assessment was based on the sediment physicochemical characterization including sediment grain size, total organic matter (OM; loss on ignition), and toxic metals including $\mathrm{Cr}, \mathrm{Co}, \mathrm{Ni}, \mathrm{Cu}, \mathrm{Zn}, \mathrm{As}, \mathrm{Cd}, \mathrm{Pb}$, and $\mathrm{Hg}$. Sediment samples were subject to ecotoxicological analysis in order to assess the potential risk to sediment living organisms.

\section{Materials and methods}

\section{Study area and sample collection}

Tiruchirappalli city is located in the central part of the state of Tamil Nadu between a latitude of $10^{\circ} 10^{\prime}$ and $11^{\circ} 20^{\prime}$ north and a longitude of $78^{\circ} 10^{\prime}$ and $29^{\circ} 0^{\prime}$ east. The city is divided into four main areas namely Ariyamangalam, K.Abisekapuram, Golden Rock, and Sri Rangam. The city is supplied with 85 Mld (million liters per day) of water through four pumping stations located by the Cauvery River. (1) Kambarasampettai (26 Mld), (2) New Collector (32 Mld), (3) Ammamandapam (5.5 Mld), (4) Golden Rock (20 Mld), and the remaining water supply $(1.5 \mathrm{Mld})$ being sourced from ground water. The pumping stations of Kambarasampettai and New Collector are located $3 \mathrm{~km}$ upstream from the effluent discharge site (E1), and the Ammamandapam pumping station is $1 \mathrm{~km}$ upstream. The drainage system of the city is well designed to collect the rain which is conveyed by open drain, and sewage is removed by closed conduit. Seventy-seven percent of the historic Tiruchirappalli town is provided with underground sewer drainage and is well connected to the sewage treatment plant. However, newly built areas such as Golden Rock and the Sri Rangam localities are completely unsewered and the effluent released from this part of the city is released into the Cauvery River by surface channels. Tiruchirappalli city generates an average of 68 Mld of waste water but only has facilities to collect 42 Mld in its existing sewage system with the end point being the nearby water sources (Muthukumaran and Ambujam 2003). The corporation supports the small and medium-sized industries with $5 \mathrm{Mld}$ of water and the large industries meet their own water needs by being self-sustainable. The small and the medium-sized industries dump their effluent into the municipal sewage channels and the large industries discharge their effluent after initial treatment into the Uyakkondan irrigation canal which forms part of the Cauvery River. The Uyakkondan is a 1000-year-old canal built by Raja Raja Cholan and renovated by Kulothunga Cholan. The canal takes its flow from the Cauvery River and runs through Tiruchirappalli city and serves as a major source of water for more than 32,000 acres of agricultural land, 36 tanks, and also serves as the major conduit for receiving the effluent waters from the city. However, sampling of site E1 (effluent discharge point) found it free from effluents discharged by these large industries, but sewage from the municipality, the hospital, and small-scale industries was present. 
The surface sediments were collected from (1) five selected hospital outlet pipes (HOP) labeled H1, H2, H3, H4, and H5. The collection points were adjacent to the hospital effluent outlet pipe before discharge into the municipal sewage for a period of 4 months (June to September 2013) and (2) in the Cauvery River basin (CRB) at Tiruchirappalli, Tamil Nadu, India (Fig. 1). The surface sediments $(2-6 \mathrm{~cm})$ in the CRB were collected at specific points and given the following names: R0, $5 \mathrm{~km}$ upstream from the effluent discharge point on the river (as a control sample); E1, in the vicinity of effluent discharge into the river; R1, $5 \mathrm{~km}$ downstream from the effluent discharge point; R2, $10 \mathrm{~km}$ downstream from the effluent discharge point; and R3, Grand Anicut (Kallanai Dam) located $15 \mathrm{~km}$ downstream from the effluent discharge point. The sampling took place in September 2013. The sediments were collected in sterile plastic bags and stored at $4{ }^{\circ} \mathrm{C}$ until they were shipped to the F.A. Forel Institute of the University of Geneva in Switzerland for further analysis.
Analysis of sediment grain size, water content, and total organic matter

The particle grain size was measured using a Laser Coulter ${ }^{\circledR}$ LS-100 diffractometer (Beckman Coulter, Fullerton, CA, USA), following $5 \mathrm{~min}$ ultrasonic dispersal in deionized water according to the method described by Loizeau et al. (1994). The sediment total organic matter $(\mathrm{OM})$ content was estimated by loss on ignition at $550{ }^{\circ} \mathrm{C}$ for $1 \mathrm{~h}$ in a Salvis oven (Salvis AG, Emmenbrücke, Lucerne, Switzerland).

\section{Toxic metal analysis}

Before being analyzed, sediment samples were lyophilized at $-45^{\circ} \mathrm{C}$ after homogenization and air-drying at ambient room temperature. Toxic metals including $\mathrm{Cr}, \mathrm{Co}, \mathrm{Ni}, \mathrm{Cu}, \mathrm{Zn}, \mathrm{As}$, $\mathrm{Cd}$, and $\mathrm{Pb}$ were determined by quadrupole-based inductively coupled plasma mass spectrometry (ICP-MS, Agilent model

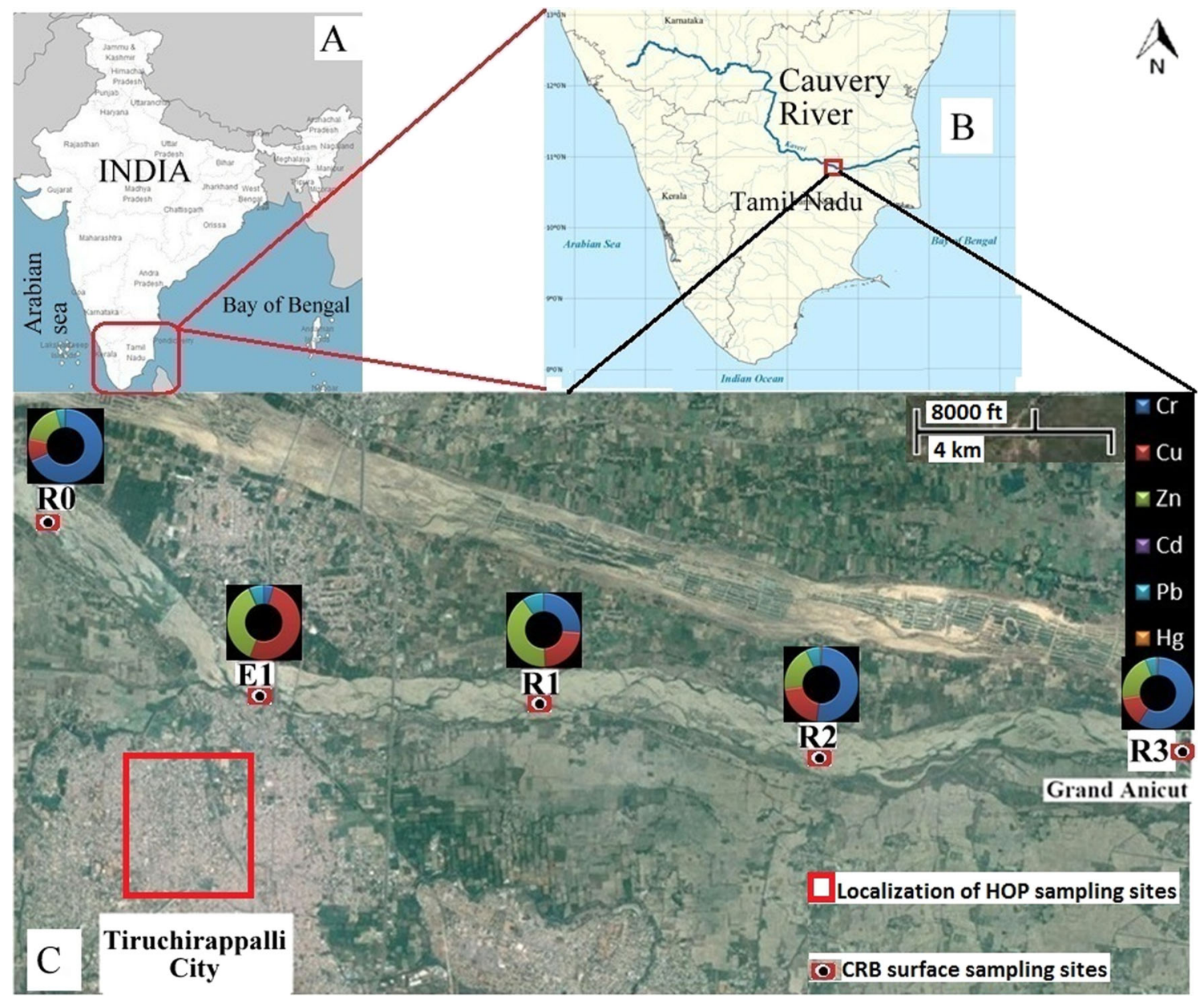

Fig. 1 a Location of study area Tamil Nadu, India. b Flow of Cauvery River map. c Location map of surface sediment sampling sites in HOP and CRB, Tiruchirappalli, Tamil Nadu, India. Graphical representation indicates the distribution of metals between the sampling sites. R0 $\left(10^{\circ} 51^{\prime}\right.$ $\left.58 \mathrm{~N} ; 78^{\circ} 39^{\prime} 57 \mathrm{E}\right)-5 \mathrm{~km}$ upstream the river before the effluent discharge point (control site), E1 $\left(10^{\circ} 50^{\prime} 17 \mathrm{~N} ; 78^{\circ} 41^{\prime} 45^{\prime \prime} \mathrm{E}\right)$ - at the vicinity of effluent discharge into the river, R1 $\left(10^{\circ} 50^{\prime} 13 \mathrm{~N} ; 78^{\circ} 44^{\prime} 00\right.$ E) $-5 \mathrm{~km}$ downstream the effluent discharge point, R2 $\left(10^{\circ} 50^{\prime} 53 \mathrm{~N}\right.$; $\left.78^{\circ} 44^{\prime} 23 \mathrm{E}\right)-10 \mathrm{~km}$ downstream the effluent discharge point, R3 $\left(10^{\circ} 49^{\prime} 54 \mathrm{~N} ; 78^{\circ} 49^{\prime} 07 \mathrm{E}\right)-$ Grand Anicut located $15 \mathrm{~km}$ downstream the effluent discharge point 
7700 series) following the digestion of sediments in Teflon bombs heated to $150{ }^{\circ} \mathrm{C}$ in analytical grade $2 \mathrm{M} \mathrm{HNO}_{3}$ (Pardos et al. 2004; Loizeau et al. 2004; Pote et al. 2008). Multi-element standard solutions at different concentrations $(0,0.02,1,5,20,100$, and $200 \mu \mathrm{g} / \mathrm{L})$ were used for calibration. Total variation coefficients of triplicate sample measurements were under $10 \%$ and chemical blanks for the procedure were less than $2 \%$ of the sample signal. The metal concentrations of sediments were expressed in ppm $\left(\mathrm{mg} \mathrm{kg}^{-1}\right.$ dry weight sediment).

Total Hg analysis was carried out using an atomic absorption spectrophotometer (AAS) for mercury determination (Advanced Mercury Analyser; AMA 254, Altec s.r.1., Czech Rep.) following the method described by Hall and Pelchat (1997) and Ross-Barraclough et al. (2002). The method is based on sample combustion, gold amalgamation, and AAS. The detection limit ( $3 \mathrm{SD}$ blank) was $0.005 \mathrm{mg} \mathrm{kg}^{-1}$ and the reproducibility better than $5 \%$.

\section{Sediment toxicity test}

The sediment sample toxicity test was performed using the TK36-Ostracodtoxkit F (MicroBio Tests Inc., Belgium) following the manufacturer's recommendations. In brief, the benthic ostracod crustacean Heterocypris incongruens cysts were hatched in standard fresh water at $25{ }^{\circ} \mathrm{C}$ with permanent illumination (approximately 3000-4000 lx) $54 \mathrm{~h}$ before the tests. The neonates were then measured for length and immediately placed in test wells. One test well consisted of $1 \mathrm{~mL}$ test sediment, $2 \mathrm{~mL}$ standard fresh water, $2 \mathrm{~mL}$ algal food suspension (provided with the kit), and ten living ostracods. The test plates containing six wells were sealed with parafilm, covered with a lid, and incubated at $25{ }^{\circ} \mathrm{C}$ in the dark for 6 days. At the end of the test, the mortality (\%) of the organisms was determined using the formula $\%$ Mortality $=B / A \times$ 100 , where $B=$ total number of dead ostracods and $A=$ total number of ostracods added to the test plate. In addition, the length of the surviving ostracods was measured using a micrometric strip placed at the bottom of the glass microscope plate. Growth inhibition was calculated using the following formula (Oleszczuk 2007):

Growth inhibition $(\%)=100$

$-[$ (growth in test sediment/growth in reference sediment $) \times 100]$

\section{Data analysis}

Triplicate measurements were made for all analyses of sediment samples. Statistical processing of data (Spearman's rankorder correlation) was performed using SigmaStat 11.0 (Systat Software, Inc., USA).

\section{Results and discussion}

\section{Sediment organic matter and particle grain size}

Sediment characteristics including total organic matter measured by loss on ignition and particle grain size are shown in Table 1. The sediment samples from all of the sites in the HOP were generally loamy-sandy sediments (Mubedi et al. 2013). The sediments were mainly composed of sand and silts, with values ranging from 22.5 to $79.8 \%$ and $18.5-77.4 \%$, respectively. OM in sediments ranged from 0.6 to $10.7 \%$. Sediments from CRB were mainly sandy sediments (with sand content ranging from 44.9 to $100 \%$ ) and presented the lowest values of organic matter content (maximum value $4.2 \%$ ). Furthermore, these sediments presented the lowest values of clay (maximum value $0.5 \%$ ).

Particle size distribution in the CRB was influenced by the hydrodynamic aspects of the river and probably by stream dynamics and the action of sewage inputs as well as wave action that can create a great deal of energy (Pote et al. 2008; Mwanamoki et al. 2014a, b, c). With the exception of site E1, the coarser sediments were located in other sites with median values of $323.7,278.4,411.3$, and $553.2 \mu \mathrm{m}$ for R0, $\mathrm{R} 1, \mathrm{R} 2$, and R3, respectively. The median value at E1 was $53.5 \mu \mathrm{m}$. Compared to other sampling sites in the river, the sediments in this site had a low sand content (44.9\%). The total OM content of the sediments does not show considerable variation between sampling sites, ranging between 0.1 and $4.2 \%$. Previous studies by the authors have reported that distribution of sediment OM and grain size in freshwaters, lakes, rivers, and reservoirs display large variations (Haller et al. 2009; Pote et al. 2008). According to the results of these studies, the organic matter in non-contaminated freshwater sediments varied from 0.1 to $6.0 \%$. Consequently, the sediment of the CRB can be considered to be unpolluted by organic matter. For example, OM can reach more than $30 \%$ in sediments contaminated by the municipal WWTP effluent waters (Pote et al. 2008). The low organic matter content in the sediment from CRB can be explained by the hydrodynamic aspects of water flow and also by crops grown inside the watershed and by areas surrounding the river being forested.

\section{Toxic element concentrations in sediment samples}

The results of the trace metal analysis are reported in Table 2. The concentration of metals in the sediments sampled from HOP sites varied considerably, ranging from 21 to 1851,23 210, 66-987, 0.8-3.7, 9.6-82.5, and 0.18-16.8 $\mathrm{mg} \mathrm{kg}^{-1}$ for $\mathrm{Cr}, \mathrm{Cu}, \mathrm{Zn}, \mathrm{As}, \mathrm{Pb}$, and $\mathrm{Hg}$, respectively. The same tendency was observed in sediment samples from the CRB, but the concentration values of all metals are generally low, except for site E1. Compared with other sampling points on the river, the maximum metal levels were generally observed in site E1. 
Table 1 Water content, total organic matter, and particle grain size in sediment samples collected from HOP and CRB sampling sites

\begin{tabular}{lrrllllc}
\hline $\begin{array}{l}\text { Sample } \\
\text { number }\end{array}$ & $\mathrm{H}_{2} \mathrm{O}(\%)$ & $\mathrm{OM}(\%)$ & $\mathrm{CaCO}_{3}(\%)$ & Clay $(\%)$ & Silt $(\%)$ & Sand $(\%)$ & $\begin{array}{c}\text { Median particle } \\
\text { grain size }(\mu \mathrm{m})\end{array}$ \\
\hline H1 June & 10.8 & 5.4 & 1.6 & 0.7 & 41.7 & 57.6 & 92.5 \\
H2 June & 7.5 & 0.6 & 0.2 & 0.5 & 47.5 & 52.0 & 67.8 \\
H3 June & 20.0 & 3.6 & 0.8 & 0.3 & 42.1 & 57.6 & 115.8 \\
H4 June & 7.7 & 0.7 & 0.2 & 0.4 & 23.8 & 75.8 & 190.0 \\
H5 June & 9.7 & 10.7 & 2.5 & 1.0 & 55.7 & 43.3 & 46.3 \\
H1 July & 17.2 & 3.7 & 0.4 & 0.6 & 64.4 & 35.0 & 38.2 \\
H2 July & 17.1 & 2.9 & 0.3 & 0.3 & 68.5 & 31.2 & 33.7 \\
H3 July & 12.5 & 7.6 & 0.2 & 0.2 & 33.8 & 66.1 & 118.2 \\
H4 July & 8.6 & 0.8 & 0.3 & 1.7 & 79.8 & 18.5 & 18.6 \\
H5 July & 15.7 & 1.0 & 0.2 & 0.1 & 22.5 & 77.4 & 164.7 \\
H1 Aug & 16.9 & 6.2 & 1.3 & 1.4 & 72.2 & 26.5 & 24.0 \\
H2 Aug & 30.1 & 3.9 & 0.8 & 1.3 & 70.7 & 28.0 & 28.6 \\
H3 Aug & 3.3 & 3.1 & 0.9 & 0.4 & 48.1 & 51.6 & 66.2 \\
H4 Aug & 10.7 & 2.0 & 0.4 & 0.3 & 32.1 & 67.5 & 148.2 \\
H5 Aug & 15.9 & 3.7 & 0.6 & 0.8 & 51.6 & 47.7 & 57.8 \\
H1 Sep & 12.7 & 2.1 & 0.6 & 0.5 & 57.2 & 42.3 & 41.8 \\
H2 Sep & 9.8 & 0.7 & 0.2 & 0.4 & 38.0 & 61.6 & 172.4 \\
H3 Sep & 7.0 & 1.0 & 0.3 & 0.4 & 28.5 & 71.1 & 163.0 \\
H4 Sep & 7.5 & 0.6 & 0.2 & 0.2 & 38.2 & 61.6 & 153.4 \\
H5 Sep & 10.9 & 0.6 & 0.2 & 0.2 & 34.2 & 65.6 & 247.5 \\
R0 & 6.3 & 4.2 & 0.0 & 0.1 & 1.5 & 98.5 & 323.7 \\
E1 & 20.0 & 2.3 & 0.5 & 0.0 & 55.1 & 44.9 & 53.5 \\
R1 & 7.7 & 0.9 & 0.2 & 0.5 & 16.0 & 83.4 & 278.4 \\
R2 & 6.0 & 0.1 & 0.0 & 0.2 & 8.5 & 91.4 & 411.3 \\
R3 & 7.3 & 0.4 & 0.1 & 0.0 & 0.0 & 100.0 & 553.2 \\
\hline All & & & & & & \\
\end{tabular}

All analyses were performed in triplicate and the standard deviation was less than $4.5 \%$ of average

Sediment samples: $H 1$ hospital 1 sediment collection point, $H 2$ hospital 2 sediment collection point, $H 3$ hospital 3 sediment collection point, $H 4$ hospital 4 sediment collection point, $H 5$ hospital 5 sediment collection point
For example, values of 906,650 , and $111 \mathrm{mg} \mathrm{kg}^{-1}$ for $\mathrm{Cu}, \mathrm{Zn}$, and $\mathrm{Pb}$, respectively, were recorded in this site, which is characterized by the discharge of untreated municipal and hospital effluent waters. Effluent has no influence at site R0 (considered as a control site), located upstream of E1. However, the metal levels in sediments from this site were very low. An evaluation of the potential deleterious effects of the toxic metals on benthic fauna, applying the consensus-based guidelines for sediment quality (MacDonald et al. 2000; Long et al. 2006), estimates the hazard these sediment may represent to the biota. The concentration of toxic metal including $\mathrm{Cr}, \mathrm{Cu}$, $\mathrm{Zn}, \mathrm{As}, \mathrm{Cd}, \mathrm{Pb}$, and $\mathrm{Hg}$ obtained in this study were primarily compared with the Sediment Quality Guidelines for the Protection of Aquatic Life (CCME EPC-98E 1999) and sediments were also evaluated for their toxicity using the ostracod as the test organism. According to Wildi et al. (2004), finegrained sediment with higher water content is unstable and mainly subject to erosion by currents and waves, gravity process, and human activities. In this case, the current of the river water may lead to erosion and resuspension of contaminated sediments and favor the uptake of contaminants by the aquatic living organisms present. Consequently, the metal concentration values from the sediment samples' fine fractions $(<63 \mu \mathrm{m})$ need to be considered which was $20 \times(\mathrm{Cr})$ to $35 \times$ $(\mathrm{Hg})$ higher in the HOP site and $5 \times(\mathrm{Hg})$ to $13 \times(\mathrm{Cr})$ higher in the CRB (Fig. 2) than the PELs (probable effect levels) (CCME EPC-98E 1999). According to previous studies by the authors (Pote et al. 2008; Haller et al. 2011; Thevenon et al. 2011a, b; Thevenon and Pote 2012; Mubedi et al. 2013; Ngelinkoto et al. 2013; Mwanamoki et al. 2014a, c), and compared to the results of this study, the sediment receiving systems from HOP and CRB (especially in site E1) can be considered to be heavily contaminated by toxic metals, especially $\mathrm{Cr}, \mathrm{Cu}, \mathrm{Zn}, \mathrm{Cd}, \mathrm{Pb}$, and $\mathrm{Hg}$, which are frequently associated with adverse biological effects.

\section{Ecotoxicity test analysis}

A bioindicator is a group of organisms that provide information on the environmental conditions, with effective variables 
Table 2 Metal content $\left(\mathrm{mg} \mathrm{kg}^{-1}\right.$ dry weight sediment) ${ }^{\mathrm{c}}$ of surface sediments analyzed by ICP-MS and by AMA for total mercury

\begin{tabular}{|c|c|c|c|c|c|c|c|c|c|c|}
\hline Sample site & Month & $\mathrm{Cr}$ & $\mathrm{Co}$ & $\mathrm{Ni}$ & $\mathrm{Cu}$ & $\mathrm{Zn}$ & As & $\mathrm{Cd}$ & $\mathrm{Pb}$ & $\mathrm{Hg}$ \\
\hline \multirow[t]{6}{*}{ H1 } & Jun $2012^{d}$ & 58.1 & 7.95 & 28.32 & 67.5 & 1652.2 & 1.7 & 1.4 & 45.5 & 2.46 \\
\hline & Jun 2013 & 1851 & 10.9 & 42.3 & 183.6 & 986.9 & 3.7 & 1.9 & 29.3 & 1.62 \\
\hline & Jul 2013 & 87.6 & 13.7 & 51.7 & 59.6 & 288.2 & 1.6 & 0.4 & 30.4 & 1.4 \\
\hline & Aug 2013 & 978.9 & 11.9 & 47.4 & 112.2 & $\mathbf{5 7 3 . 7}$ & 2.6 & 1 & 29.2 & 1.67 \\
\hline & Sep $2012^{d}$ & 85.4 & 5.7 & 15.3 & 28.85 & 313.9 & 1.3 & 0.33 & 36.3 & 0.71 \\
\hline & Sep 2013 & 71.4 & 11.2 & 38 & 34.2 & 128.6 & 1.4 & 0.2 & 29.2 & 0.4 \\
\hline \multirow[t]{6}{*}{$\mathrm{H} 2$} & Jun $2012^{d}$ & 29.41 & 4.22 & 12.78 & 9.84 & 44.47 & 0.6 & 0.06 & 12.73 & 0.38 \\
\hline & Jun 2013 & 74.9 & 10.4 & 38.2 & 26.3 & 65.8 & 0.9 & 0.1 & 27.9 & 0.26 \\
\hline & Jul 2013 & 73.7 & 11.8 & 45.9 & 60.3 & 293 & 1.5 & 0.4 & 27.5 & 1.18 \\
\hline & Aug 2013 & 131.8 & 22.8 & 80.4 & 75.9 & 321.9 & 2.3 & 0.5 & 82.5 & 1.37 \\
\hline & Sep $2012^{d}$ & 40.6 & 5.3 & 19.9 & 45.1 & 263.2 & 1.43 & 0.5 & 29.5 & 1.83 \\
\hline & Sep 2013 & 85 & 13.6 & 49.6 & 43.1 & 130.6 & 1.3 & 0.2 & 38.4 & 0.3 \\
\hline \multirow[t]{6}{*}{ H3 } & Jun $2012^{d}$ & 148.8 & 1.78 & 10.73 & 52.3 & 274.9 & 0.9 & 0.6 & 16.6 & 14.81 \\
\hline & Jun 2013 & 53.1 & 7.9 & 41.5 & 155.8 & 505 & 1.8 & 1.4 & 42.7 & 16.81 \\
\hline & Jul 2013 & 21.3 & 2.4 & 12.4 & 210.2 & 591.4 & 1 & 0.4 & 9.6 & 1.28 \\
\hline & Aug 2013 & 96.5 & 16.1 & 60 & 86.6 & 344 & 1.7 & 0.6 & 52.1 & 3.62 \\
\hline & Sep $2012^{d}$ & 15.8 & 2.08 & 7.58 & 19.8 & 75.19 & 1.03 & 0.3 & 5.81 & 2.27 \\
\hline & Sep 2013 & 86.8 & 13.6 & 49.4 & 42.7 & 173.1 & 1.3 & 0.2 & 43.9 & 3.24 \\
\hline \multirow[t]{6}{*}{$\mathrm{H} 4$} & Jun $2012^{d}$ & 16.6 & 2.1 & 6.87 & 13.89 & 88.84 & 1.8 & 0.08 & 5.98 & 3.89 \\
\hline & Jun 2013 & 74.1 & 11.1 & 40.6 & 29 & 81.6 & 0.9 & 0.1 & 28.3 & 0.39 \\
\hline & Jul 2013 & 108.4 & 15.5 & 57.6 & 40.5 & 97.7 & 1.5 & 0.1 & 36.8 & 0.26 \\
\hline & Aug 2013 & 69.6 & 10.6 & 38.9 & 81.1 & 138.7 & 1.1 & 0.2 & 31.4 & 0.67 \\
\hline & Sep $2012^{\mathrm{d}}$ & 21.2 & 3.09 & 10.21 & 71.57 & 75.12 & 0.59 & 0.09 & 7.48 & 2.67 \\
\hline & Sep 2013 & 70.9 & 10.6 & 36.7 & 27.6 & 98.2 & 2.7 & 0.2 & 25.8 & 0.29 \\
\hline \multirow[t]{6}{*}{ H5 } & Jun $2012^{\mathrm{d}}$ & 22.93 & 3.23 & 10.48 & 25.11 & 126.8 & 1.01 & 0.22 & 17.2 & 1.7 \\
\hline & Jun 2013 & 1340.2 & 5.9 & 25.6 & 107.9 & 659.9 & 2.3 & 0.9 & 14.4 & 5.46 \\
\hline & Jul 2013 & 56.7 & 8.5 & 31.4 & 22.9 & 66.7 & 0.8 & 0.1 & 18.2 & 0.18 \\
\hline & Aug 2013 & 115.5 & 20.2 & 71.2 & 67.7 & 296.9 & 2 & 0.5 & 64.1 & 0.84 \\
\hline & Sep $2012^{\mathrm{d}}$ & 19.78 & 3.13 & 10.16 & 23.59 & 109.78 & 0.79 & 0.21 & 8.9 & 1.71 \\
\hline & Sep 2013 & 108.6 & 12.2 & 43.4 & 39 & 114.2 & 1.4 & 0.2 & 32.9 & 0.21 \\
\hline \multirow[t]{5}{*}{ River } & R0 & 18.9 & 2.7 & 7.2 & 2.7 & 4.9 & 0.2 & 0 & 1.1 & 0.04 \\
\hline & E1 & 74.6 & 9.7 & 51.4 & 906.3 & 649.8 & 2.8 & 6.3 & 111.4 & 0.99 \\
\hline & $\mathrm{R} 1$ & 34.4 & 5.5 & 17.4 & 30.4 & 53.6 & 0.6 & 0.1 & 12.4 & 0.21 \\
\hline & $\mathrm{R} 2$ & 13.9 & 2.7 & 6.4 & 5.6 & 5.4 & 0.2 & 0 & 1.7 & 0.16 \\
\hline & $\mathrm{R} 3$ & 31.7 & 4.3 & 12.4 & 7.3 & 11.6 & 0.4 & 0 & 2.8 & 0.36 \\
\hline $\begin{array}{l}\text { Rec. }^{\mathrm{b}} \\
\text { Max conc }^{\mathrm{a}}\end{array}$ & & 37.3 & & & 35.7 & 123 & 5.9 & 0.6 & 35 & 0.17 \\
\hline
\end{tabular}

The values in bold represent the concentration of the heavy metals above the recommended concentration according to the Sediment Quality Guidelines for the Protection of Aquatic Life recommendation (CCME EPC-98E, 1999)

Sediment samples: $H 1$ hospital 1 sediment collection point, $H 2$ hospital 2 sediment collection point, $H 3$ hospital 3 sediment collection point, $H 4$ hospital 4 sediment collection point, $H 5$ hospital 5 sediment collection point

${ }^{\text {a }}$ Concentration unit: $\mathrm{mg} \mathrm{kg}^{-1}$ dry weight sediment

${ }^{\mathrm{b}}$ Rec. "Sediment Quality Guidelines for the Protection of Aquatic Life" recommendations

${ }^{\mathrm{c}}$ All analyses were performed in triplicate and the standard deviation was less than $3 \%$ of average

${ }^{\mathrm{d}}$ Data from 2012 (Mubedi et al. 2013)

being their mere presence or absence, abundance, age structure, or a statistical index applied to their populations (Rinderhagen et al. 2000). Ostracods are usually included as useful bioindicators in the changing environmental conditions in recent and quaternary environments (Anadon et al. 2002; Boomer and Eisenhauer 2002). 


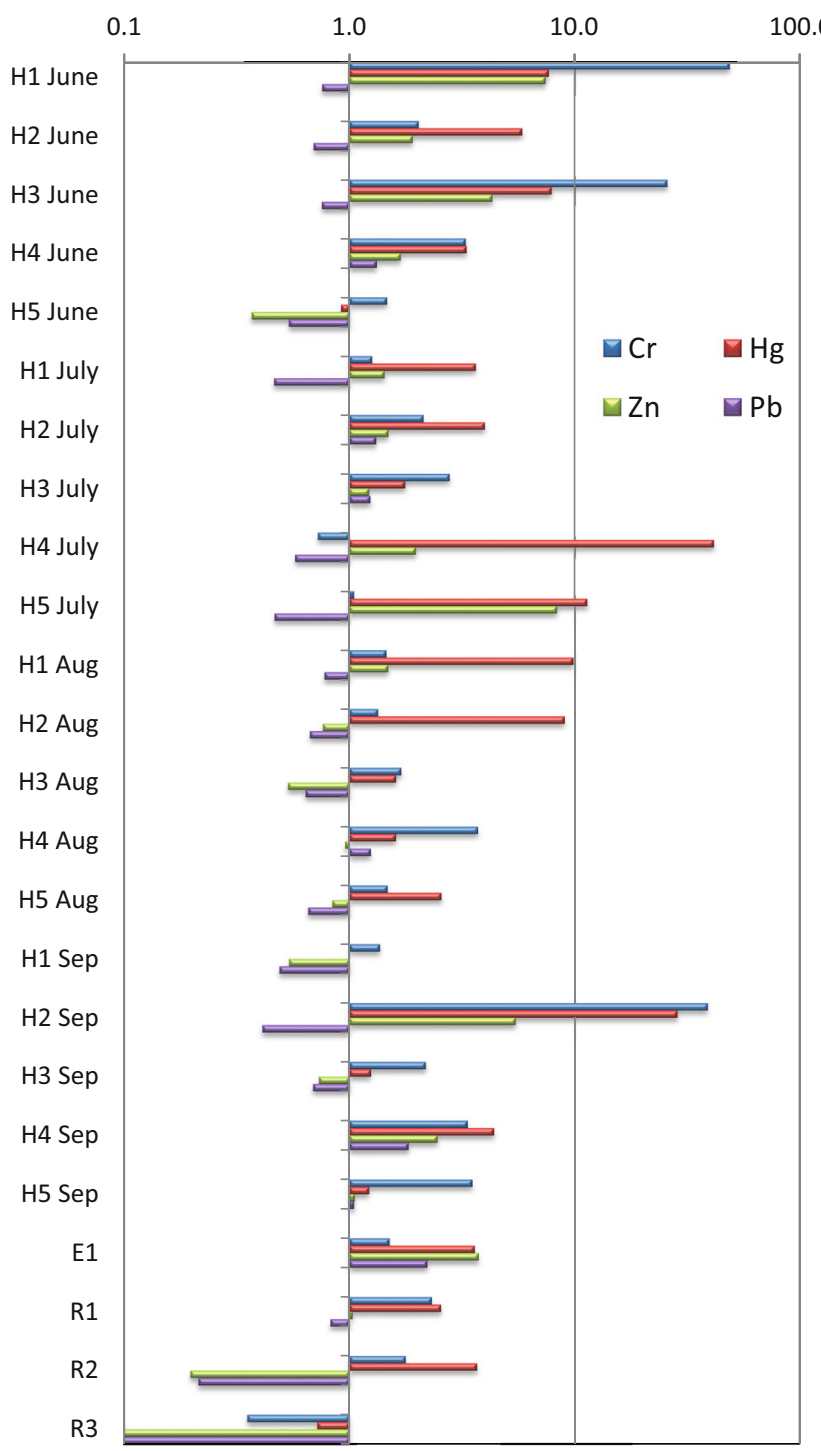

Fig. 2 Graphical representation of probable effect levels (PEL) ratio calculated for $\mathrm{Cr}, \mathrm{Zn}, \mathrm{Pb}$, and $\mathrm{Hg}$ in the fine sediments $(<63 \mu \mathrm{m})$, and values above the recommended values are expressed using the log-10 scale for the $x$-axis. *Sediment Quality Guidelines for the Protection of Aquatic Life recommendation (CCME EPC-98E 1999)

Previous studies have pointed out the almost instantaneous population response of these bioindicators to anthropogenic impacts such as oil spills or industrial sewages (Mostafawi 2001). The study presented in this paper used the potential of this group (ostracods) as possible bioindicators of environmental changes to the receiving systems induced by the hospital and urban effluent waters in tropical conditions (Ruiz et al. 2006). The percentage of growth inhibition and the mortality rate of ostracods are presented in Table 3 . The mortality rate percentage in the sediment samples collected from the HOP ranged from 22.8 to $100 \%$, and the mortality rate in the sediment samples collected along CRB ranged from 18.18 to $87.5 \%$. The growth inhibition calculated for the samples
Table 3 Percentages of mortality and growth inhibition of ostracods (Heterocypris incongruens) exposed to the sediments from the HOP and CRB sampling sites

\begin{tabular}{lcc}
\hline Sample & \% Mortality & \% Growth inhibition \\
\hline H1 June & 92.00 & $\mathrm{n} / \mathrm{a}$ \\
H3 June & 26.67 & $64.2 \pm 9$ \\
H5 June & 71.88 & $\mathrm{n} / \mathrm{a}$ \\
H5 July & 82.30 & $\mathrm{n} / \mathrm{a}$ \\
H4 July & 100.00 & $\mathrm{n} / \mathrm{a}$ \\
H3 Aug & 91.67 & $\mathrm{n} / \mathrm{a}$ \\
H1 Aug & 28.90 & $51.9 \pm 9$ \\
H2 Sep & 22.80 & $61.9 \pm 9$ \\
H3 Sep & 87.50 & $\mathrm{n} / \mathrm{a}$ \\
R0 & 18.18 & $13.2 \pm 6$ \\
E1 & 87.50 & $\mathrm{n} / \mathrm{a}$ \\
R1 & 22.58 & $53.7 \pm 6$ \\
R2 & 68.97 & $\mathrm{n} / \mathrm{a}$ \\
R3 & 24.32 & $75.4 \pm 6$ \\
\hline
\end{tabular}

Sediment samples: $H 1$ hospital 1 sediment collection point, $H 2$ hospital 2 sediment collection point, $H 3$ hospital 3 sediment collection point, $H 4$ hospital 4 sediment collection point, $H 5$ hospital 5 sediment collection point. $n / a$ Growth inhibition not determined if the mortality rate is more than $30 \%$ according to the manufacturer's recommendation

with less than $30 \%$ mortality rate (as per the manufacturer's instructions) ranged from 51.9 to $64.2 \%$ in the 4 months of sample collection at the HOP and 13.2 to $75.4 \%$ in the sediments collected in the CRB. The control site (R0) showed the smallest effect on the benthic ostracods with an $18.18 \%$ mortality rate and $13.2 \%$ growth inhibition whereas H4 July samples showed the highest mortality rate of $100 \%$ and R3 sediment samples had the highest growth inhibition rate of $75.4 \%$. The ecotoxicological results indicate the potential risk of organisms exposed to the sediment samples studied. The impact on both the mortality and/or growth inhibition of the ostracods is notable. The mortality rate of sample H4 July is $100 \%$, which is explained by the fact that besides metals there are many other compounds present in the hospital effluent that could accumulate in the sediments. Remarkably, H4 July has metal values that are lower than H1 August, which would have been more toxic, but $100 \%$ mortality was observed in $\mathrm{H} 4$ July and so only $28.90 \%$ was observed in H1 August. These results indicate that sediment could carry other sources of contaminants/pollutants which could impact on the growth of the ostracods added to the test sediments. However, a detailed study should be carried out in order to fully understand the toxic effects of the hazardous substances present in the sediments by combining physicochemical and ecotoxicological studies (Verlicchi et al. 2010; Mubedi et al. 2013). 
Table 4 Spearman's rank-order correlation of selected parameters ${ }^{\mathrm{a}}$ analyzed in the surface sediments

\begin{tabular}{|c|c|c|c|c|c|c|c|c|}
\hline & $\begin{array}{l}\text { Median grain } \\
\text { size }\end{array}$ & $\mathrm{Cr}$ & $\mathrm{Cu}$ & $\mathrm{Zn}$ & As & $\mathrm{Cd}$ & $\mathrm{Pb}$ & $\mathrm{Hg}$ \\
\hline $\mathrm{OM}$ & -0.531 & 0.362 & 0.688 & 0.734 & 0.476 & 0.664 & 0.141 & 0.626 \\
\hline $\begin{array}{l}\text { Median grain } \\
\text { size }\end{array}$ & & -0.618 & -0.576 & -0.616 & -0.684 & -0.609 & -0.475 & $-\mathbf{0 . 5 3 7}$ \\
\hline $\mathrm{Cr}$ & & & 0.476 & 0.579 & 0.718 & 0.615 & 0.593 & 0.484 \\
\hline $\mathrm{Cu}$ & & & & 0.958 & 0.716 & 0.914 & 0.546 & 0.796 \\
\hline $\mathrm{Zn}$ & & & & & 0.802 & 0.962 & 0.512 & 0.852 \\
\hline As & & & & & & 0.848 & $\mathbf{0 . 5 9 7}$ & 0.647 \\
\hline $\mathrm{Cd}$ & & & & & & & 0.604 & 0.825 \\
\hline $\mathrm{Pb}$ & & & & & & & & 0.46 \\
\hline
\end{tabular}

${ }^{a}$ Parameters include toxic metals, median grain size, and total organic content $[n=25$, statistically significant coefficients $(p<0.05)$ are in bold]

\section{Correlation between metals, $\mathrm{OM}$, and median grain size}

The Spearman's rank-order correlation values are presented in Table 4. The positive mutual correlation of all of the metals is significant, and correlation coefficients ranged from 0.3 to 0.9 . Furthermore, there is a positive correlation between the metals and $\mathrm{OM}$ in the sediment samples with values ranging from 0.4 to 0.7 . These results indicate that metals and OM could be considered to originate from common sources and they are carried to the receiving system by common transporters. A negative correlation was found between particle grain size and the other parameters analyzed. The observation of the negative correlation with the metals and the particle grain size can probably be explained by the hypothesis that the grain size is not a strong factor influencing the transport of contaminants to receiving systems (Salomons and Förstner 1984; Haller et al. 2009). In general, the correlation between the sediment median grain size and the trace elements indicates that the metals are not of natural (geological) origin and that their deposition in CRB is linked to the transport of municipal sewage. This is also evident from the positive correlation between total organic content and the metals in sediments. This observation is also supported by the fact that the contaminants are attached to both large organic and small inorganic particles such as clay and they could behave in a similar way in transporting contaminants to the receiving system (Pote et al. 2008, Zhao et al. 2014).

\section{Conclusion}

The results of this study demonstrate that the values of toxic metals from the HOP are higher than the values observed in sediments collected from $\mathrm{CRB}$ (with the exception of $\mathrm{Cu}$ and $\mathrm{Pb}$ ). The higher concentration of $\mathrm{Cu}$ and $\mathrm{Pb}$ could be explained by input from other non-identified sources. These values vary according to the sampling period and it is highly likely that toxic metals released/accumulated in the sediments of the municipal sewage could be transported to the receiving system in large amounts during floods and periods of rain. The results presented in this paper suggest that the hospital effluents released into the municipal sewage without prior treatment could act as a potential source of pollutants in the CRB sediments. The ecotoxicological tests performed on the sediment samples confirm the potential risk to living organisms in the aquatic environment. According to previous studies by the authors (Pardos et al. 2004; Haller et al. 2011; Mubedi et al. 2013; Mwanamoki et al. 2014a), in addition to metals, the toxicity can be explained by the presence of a large number of compounds found in untreated or partially treated effluent waters, which can accumulate in sediments. Consequently, the results of this study recommend further studies be carried out to assess other parameters such as persistent organic pollutants, drugs, antibiotics, and other drugresistant microbial contaminations. The results of the study presented in this paper provide a strong argument for treating hospital effluents with technologies used in modern industrial and urban sewage treatment plants. Therefore, continuous monitoring of the accumulation of potential toxic micro-pollutants in the receiving system should be considered and further studies to provide baseline information about other potential contaminants and bio-accumulation of toxic substances in the aquatic living organisms of the receiving system are also recommended.

Acknowledgments We are grateful to financial sources; the Swiss National Science Foundation (grant no. 31003A_150163/1); Bourse Augustin Lombard 2013 for field sampling. Naresh Devarajan is a $\mathrm{Ph}$.D. student supported by Ernst and Lucie Schmidheiny Foundation. This result presents the triplicate collaboration between University of Geneva (Forel Institute), University of Kinshasa and Pedagogic National University of Congo (Democratic Republic of Congo), and Jamal Mohamed College-Bharathidasan University (India). Clive Prestt kindly revised and checked the English of the manuscript.

Compliance with ethical standards Sediment samples were collected from public areas and facilities. We confirm that the field studies did not involve endangered and protected species. The funder had no role in study design, data collection and analysis, decision to publish, or preparation of the manuscript. 
Conflict of interest The authors declare no conflict of interest.

\section{Reference}

Anadon P, Gliozzi E, Manzini I (2002) Paleoenvironmental reconstruction of marginal marine environments from combined paleoecological and geochemical analysis on ostracods. In: Holmes JA, Chivas AR (eds) The Ostracoda: applications in Quaternary research. Geophysical Monograph 131. American Geophysical Union, Washington, DC, pp 227-247

Boomer I, Eisenhauer G (2002) Ostracod faunas as palaeoenvironmental indicators in marginal marine environments. In: Holmes JA, Chivas AR (eds) The Ostracoda: applications in Quaternary research. Geophysical Monograph 131. American Geophysical Union, Washington, DC, pp 135-149

Cantwell MG, Burgess RM, Kester DR (2002) Release and phase partitioning of metals from anoxic estuarine sediments during periods of simulated resuspension. Environ Sci Technol 36:5328-5334

CCME EPC-98E (Canadian Council of Ministers of the Environment) (1999) Canadian Sediment Quality Guidelines for the protection of Aquatic Life. Publication No. 1299; ISBN 1-89699734-1. http://www.ccme.ca/

Gillan CD, Danis B, Pernet P, Joly G, Dubois P (2005) Structure of sediment-associated microbial communities along a heavy-metal contamination gradient in the marine environment. Appl Environ Microbiol 71:679-690

Hall GEM, Pelchat P (1997) Evaluation of a direct solid sampling atomic absorption spectrometer for the trace determination of mercury in geological samples. Analyst 122:921-924

Haller L, Poté J, Loizeau J-L, Wildi W (2009) Distribution and survival of faecal indicator bacteria in the sediments of the Bay of Vidy, Lake Geneva, Switzerland. Ecol Indic 9:540-547

Haller L, Tonolla M, Zopfi J, Peduzzi R, Wildi W, Poté J (2011) Composition of bacterial and archaeal communities in freshwater sediments with different contamination levels (Lake Geneva, Switzerland). Water Res 45:1213-1228

Halling-Sorensen B, Nors Nielsen S, Lanzky PF, Ingerslev F, Holten Lutzhoft HC, Jorgensen SE (1998) Occurrence, fate and effects of pharmaceutical substances in the environment-a review. Chemosphere 36(2):357-393

Kalavathy S, Rakesh Sharma T, Sureshkumar P (2011) Arch Environ Sci 5:55-61

Kang Y, Sheng G, Fu J, Mai B, Zhang G, Lin Z, Min Y (2000) Polychlorinated biphenyls in surface sediments from the Pearl River Delta and Macau. Mar Pollut Bull 40:794-797

Loizeau JL, Arbouillle D, Santiago S, Vernet JP (1994) Evaluation of a wide range laser diffraction grain size analyser for use with sediments. Sedimentology 41:353-361

Loizeau JL, Pardos M, Monna F, Peytremann C, Haller L, Dominik J (2004) The impact of a sewage treatment plant's effluent on sediment quality in a small bay in Lake Geneva (Switzerland-France). Part 2: temporal evolution of heavy metals. Lakes Reserv Res Manag 9:53-63

Long ER, Ingersoll CG, MacDonald DD (2006) Calculation and uses of mean sediment quality guideline quotients: a critical review. Environ Sci Technol 40:1726-1736

MacDonald DD, Ingersoll CG, Berger T (2000) Development and evaluation of consensus-based sediment quality guidelines for freshwater ecosystems. Arch Environ Contam Toxicol 39:20-31

Mostafawi N (2001) How severely was the Persian Gulf affected by oil spills following the 1991 Gulf War. Environ Geol 40:1185-1191

Mubedi JI, Naresh D, Severine LF, John KM, Emmanuel KA, Periyasamy S, Kandasamy P, Pius TM, Walter W, John P (2013)
Effects of untreated hospital effluents on the accumulation of toxic metals in sediments of receiving system under tropical conditions: case of South India and Democratic Republic of Congo. Chemosphere 93:1070-1076

Muthukumaran N, Ambujam NK (2003) Wastewater treatment and management in urban areas - a case study of Tiruchirappalli City, Tamil Nadu, India. In: Bunch MJ, Madha Suresh V, Vasantha Kumaran T (eds) Proceedings of the Third International Conference on Environment and Health, Chennai, India, 15-17 December, 2003. Department of Geography, University of Madras and Faculty of Environmental Studies, York University, Chennai, pp 284-289

Mwanamoki PM, Devarajan N, Thevenon F, Birane N, Luiz FA, Grandjean D, Pius TM, Prabakar K, Mubedi JI, Christophe GK, Wildi W, Poté J (2014a) Trace metals and persistent organic pollutants in sediments from river-reservoir systems in Democratic Republic of Congo (DRC): spatial distribution and potential ecotoxicological effects. Chemosphere 111:485-492

Mwanamoki PM, Devarajan N, Thevenon F et al (2014b) Assessment of pathogenic bacteria in water and sediment from a water reservoir under tropical conditions (Lake Ma Vallée), Kinshasa Democratic Republic of Congo. Environ Monit Assess. doi:10.1007/s10661014-3891-6

Mwanamoki PM, Devarajan N, Niane B, Ngelinkoto P, Thevenon F, Nlandu JW, Mpiana PT, Prabakar K, Mubedi JI, Kabele CG, Wildi W, Poté J (2014c) Trace metal distributions in the sediments from river-reservoir systems: case of the Congo River and Lake Ma Vallée, Kinshasa (Democratic Republic of Congo). Environ Sci Pollut Res. doi:10.1007/s11356-014-3381-y

Ngelinkoto P, Thevenon F, Devarajan N, Birane N, Maliani J et al (2013) Trace metal pollution in aquatic sediments and some fish species from the Kwilu-Ngongo River, Democratic Republic of Congo (Bas-Congo). Toxicol Environ Chem. doi:10.1080/02772248. 2014.910211

Oleszczuk P (2007) The toxicity of composts from sewage sludges evaluated by the direct contact tests phytotoxkit and ostracodtoxkit. Waste Manag 28:1645-1653

Pardos M, Benninghoff C, Alencastro LP, Wildi W (2004) The impact of a sewage treatment plant's effluent on sediment quality in a small bay in Lake Geneva (Switzerland-France). Part 1: spatial distribution of contaminants and the potential for biological impacts. Lakes Reserv Res Manag 9:41-52

Pote J, Haller L, Loizeau JL, Garcia Bravo A, Sastre V, Wildi W (2008) Effects of a sewage treatment plant outlet pipe extension on the distribution of contaminants in the sediments of the Bay of Vidy, Lake Geneva, Switzerland. Bioresour Technol 9:7122-7131

Rinderhagen M, Ritterhoff J, Zauke GP (2000) Crustaceans as bioindicators. In: Gerhart, A. (Ed.), Biomonitoring of polluted water-reviews on actual topics. Trans Tech Publications-Scitech Publications. Environ. Res. Forum 9:161-194

Ross-Barraclough F, Givelet N, Martinez-Cortizas A, Goodsite ME, Biester H, Shotyk W (2002) An analytical protocol for the determination of total mercury concentrations in solid peat samples. Sci Total Environ 292:129-139

Ruiz F, Abad M, Olías M, Galán E, González I, Aguilá E, Hamoumi N, Pulido I, Cantano M (2006) The present environmental scenario of the Nador Lagoon (Morocco). Environ Res 102:215-229

Salomons W, Förstner U (1984) Metals in the hydrocycle. SpringerVerlag, Berlin. p 349

Ternes TA, Joss A (2006) Human pharmaceuticals. The challenge of micropollutants in urban water management. IWA Publishing, London

Thevenon F, Pote J (2012) Water pollution history of Switzerland recorded by sediments of the large and deep Perialpine Lakes Lucerne and Geneva: water. Air Soil Pollution 223:6157-6169

Thevenon F, Graham ND, Chiaradia M, Arpagaus P, Wildi W, Poté J (2011a) Local to regional scale industrial heavy metal pollution 
recorded in sediments of large freshwater lakes in Central Europe (lakes Geneva and Lucerne) over the last centuries. Sci Total Environ 412:239-247

Thevenon F, Graham ND, Hebez A, Wildi W, Poté J (2011b) Spatiotemporal distribution of organic and inorganic pollutants from Lake Geneva (Switzerland) reveals strong interacting effects of sewage treatment plant and eutrophication on microbial abundance. Chemosphere 84:609-617

TMC 2001 (Tiruchirappalli City Municipal Corporation, Historical Population (2001) (https://www.trichycorporation.gov.in)
Verlicchi P, Galletti A, Petrovic M, Barceló D (2010) Hospital effluents as a source of emerging pollutants: an overview of micropollutants and sustainable treatment options. J Hydrol 389:416-428

Wildi W, Dominik J, Loizeau JL, Thomas RL, Favarger P-Y, Haller L, Perroud A, Peytremann C (2004) River, reservoir and lake sediment contamination by heavy metals downstream from urban areas of Switzerland. Lakes Reserv Res Manage 9:75-87

Zhao L, Mi D, Chen Y, Wang L, Sun Y (2014) Ecological risk assessment and sources of heavy metals in sediment from Daling River basin. Environ Sci Pollut Res. doi:10.1007/s11356-014-3770-2 